\title{
Estrogen Disrupts the Inhibition of Fear in Female Rats, Possibly through the Antagonistic Effects of Estrogen Receptor $\alpha(\mathrm{ER} \alpha)$ and $\mathrm{ER} \beta$
}

\author{
Donna J. Toufexis, Karyn M. Myers, Michael E. Bowser, and Michael Davis \\ Department of Psychiatry and Behavioral Sciences, Emory University School of Medicine, and The Center for Behavioral Neuroscience, Atlanta, Georgia \\ 30329
}

\begin{abstract}
The ambiguous role of estrogen in emotional learning may result from opposing actions of estrogen receptor $\alpha($ ER $\alpha)$ and ER $\beta$. Using a fear-conditioning paradigm called the $\mathrm{AX}+, \mathrm{BX}$ - discrimination, in which cue A comes to elicit fear and cue $\mathrm{B}$ becomes a safety signal, we examined the effect of $17 \beta$-estradiol (E) and selective $\mathrm{ER} \alpha$ and $\mathrm{ER} \beta$ agonists on excitatory and inhibitory fear learning. Gonadectomized (GDX) male and female rats implanted with E or selective ER $\alpha$ or ER $\beta$ agonists were trained on the $\mathrm{AX}+, \mathrm{BX}-$ discrimination and tested periodically to A, B, and AB. GDX sham-implanted male and female rats and GDX E-implanted males, but not GDX E-implanted females, exhibited less fear to $\mathrm{AB}$ than to $\mathrm{A}$, suggesting that estrogen interferes with generalization of safety signals in female rats. ER $\alpha$ and $\operatorname{ER} \beta$ agonists disrupted discrimination learning in both sexes. ER $\alpha$-implanted groups had higher fear responses to all cues than did $\mathrm{ER} \beta$-implanted groups, suggesting that these two receptors have opposing effects in aversive discrimination learning. In contrast, neither E nor ER $\alpha$ and ER $\beta$ agonists affected single-cue fear conditioning in either sex. These data suggest that E does not enhance fear in emotional learning but acts to disrupt the inhibition of fear in females only.
\end{abstract}

Key words: emotion; hormone; learning and memory; limbic; memory formation; sex difference

\section{Introduction}

Gender differences in psychiatric illness imply that women are especially susceptible to disorders of mood (Cloitre et al., 2004). Only a handful of studies have examined sex differences in fear learning (Anagnostaras et al., 1998; Pryce et al., 1999; Gupta et al., 2001; Stock et al., 2001), and studies in rodents looking at the major gonadal hormone in females, estrogen (E), are contradictory, showing that E can facilitate, disrupt, or have no effect on fear conditioning or other types of emotional learning (DiazVeliz et al., 1989; Singh et al., 1994; Markus, 1997; Wood and Shors, 1998; Shors and Leuner, 2003).

The net effect of $\mathrm{E}$ on emotion depends on the interacting effects of the two major intracellular E receptors (ER $\alpha$ and $E R \beta)$. $\mathrm{ER} \alpha$ activation increases fear and anxiety behaviors, and ER $\beta$ activation reduces these behaviors (Morgan and Pfaff, 2001; Walf et al., 2004; Lund et al., 2005; Walf and Frye, 2005). Usually the effect of $\mathrm{E}$ on fear learning is examined in paradigms such as single-cue fear conditioning, in which animals are trained to associate a cue or a context with an aversive stimulus (i.e., foot-

\footnotetext{
Received 0ct. 2, 2006; revised July 11, 2007; accepted July 11, 2007.

This work was supported by National Institutes of Mental Health Grants MH 47840, MH 58922, and MH 52384 (M.D.), MH 76869 (D.J.T.), the Woodruff Foundation, and the National Science Foundation Science and Technology Center (the Center for Behavioral Neuroscience of the National Science Foundation under Agreement Number IBN-9876754), and in part by RR00165 to the Yerkes National Primate Center.

Correspondence should be addressed to Donna J. Toufexis, Department of Psychiatry and Behavioral Sciences, Emory University School of Medicine, and The Center for Behavioral Neuroscience, 954 Gatewood Drive NE, Atlanta, GA 30329. E-mail: dtoufex@emory.edu.

DOI:10.1523/JNEUROSCI.2529-07.2007

Copyright $\odot 2007$ Society for Neuroscience $\quad$ 0270-6474/07/279729-07\$15.00/0
}

shock). These procedures measure increases in the excitatory response over training, and any effect of E on the inhibitory factors involved in emotional learning is precluded. Considering this, we used a fear conditioning training protocol called $\mathrm{AX}+, \mathrm{BX}-$ discrimination learning, which allows for a direct examination of both the excitatory (fear-provoking) and the inhibitory (fearreducing) aspects of emotional learning.

In $\mathrm{AX}+, \mathrm{BX}-$ discrimination learning, animals are presented with different conditioned stimuli (denoted $\mathrm{A}, \mathrm{B}$, and $\mathrm{X}$ ) drawn from different sensory modalities. On $\mathrm{AX}+$ trials, animals are presented with $\mathrm{A}$ and $\mathrm{X}$ in a simultaneous compound that coterminates with footshock, and on $\mathrm{BX}$ - trials animals are presented with $\mathrm{B}$ and $\mathrm{X}$ in a simultaneous compound that is not followed by footshock. Discrimination between AX and BX is indicated by an increase in acoustic startle amplitude [fearpotentiated startle (FPS)] in the presence of AX and, as training progresses, little to no fear-potentiated startle in the presence of BX (Myers and Davis, 2004). As a function of this training, A accrues excitatory value and elicits fear, whereas B becomes inhibitory (Wagner et al., 1968). This is seen in test as robust FPS to A, little FPS to B, and less FPS to an AB compound than to A alone (because $\mathrm{B}$ inhibits the fear elicited by A). This latter effect, a reduction in FPS to the compound $\mathrm{AB}$ compared with $\mathrm{A}$, signifies the ability of the safety cue to actively inhibit fear. It has been suggested that in several psychopathologies, patients have deficits in responding to safety cues (McNally, 1997; Casada and Roache, 2005; Davis et al., 2006).

The usual training procedure for fear conditioning involves a 
large number of training trials over a short period of time, which may produce a ceiling effect that can obscure group differences in fear learning. To overcome this problem, we used a slowacquisition procedure (a few training trials each day over several days) of single-cue fear conditioning and $\mathrm{AX}+, \mathrm{BX}-$ discrimination fear learning to examine the effect of sex and E on emotional learning in rats.

\section{Materials and Methods \\ Animals}

Experimentally naive gonadectomized (GDX) male and female albino Sprague Dawley rats (300-400 g) obtained from Charles River (Raleigh, NC) were used. Animals were maintained on a $12 \mathrm{~h}$ light/dark cycle (lights on at 8:00 A.M.) and had ad libitum access to food and water.

\section{Estrogen and estrogen receptor agonists}

$17 \beta$-Estradiol and two selective estrogen receptor agonists were used. The selective ER $\alpha$ agonist propyl-pyrazole-triol (PPT) has a 410 -fold greater affinity for $\operatorname{ER} \alpha$ than for $\operatorname{ER} \beta$ (Stauffer et al., 2000). The ER $\beta$ agonist diarylpropionitrile (DPN) has a 70 -fold higher affinity for $\mathrm{ER} \beta$ than for ER $\alpha$ (Meyers et al., 2001). Estradiol, PPT, and DPN were implanted subcutaneously in the form of $21 \mathrm{~d}$ release pellets $(0.25 \mathrm{mg} /$ pellet for all; Innovative Research of America, Sarasota FL). The $17 \beta$-estradiol pellet maintains plasma concentrations in the mid- to upperphysiological range $(30-40 \mathrm{pg} / \mathrm{ml})$. The doses of PPT and DPN were chosen to approximate that of the $17 \beta$-estradiol pellet because several studies using acute application of these selective agonists have used doses equal to (Walf and Frye, 2005) or greater (Lund et al., 2005) than those used here and produced reliable behavioral effects. By using the low end of the dose range that produces behavioral effects, we tried to minimize the possibility of nonselective E receptor effects and pharmacological effects that may be caused by prolonged exposure to supraphysiological doses.

\section{Apparatus}

Animals were trained and tested in $8 \times 15 \times 15 \mathrm{~cm}$ Plexiglas and wiremesh cages suspended between compression springs, as described previously (Cassella and Davis, 1986). Cage movement resulted in displacement of an accelerometer whose analog output was integrated, amplified, and digitized on a scale of 1-2500 units by an InstruNET device interfaced to a Macintosh G3 computer. Startle amplitude was defined as the peak accelerometer voltage that occurs during the first $200 \mathrm{~ms}$ after onset of the startle stimulus. Background noise ( $60 \mathrm{~dB}$ wide-band) was delivered through high-frequency speakers located $5 \mathrm{~cm}$ in front of each cage.

\section{Stimuli}

$\mathrm{A}, \mathrm{B}$, and $\mathrm{X}$ were represented by light, white noise, and fan cues (counterbalanced), and $\mathrm{C}$ was presented as a pure tone. The light (3.7 s, 80 lux) was produced by an $8 \mathrm{~W}$ fluorescent bulb $(100 \mu$ s rise time) located $10 \mathrm{~cm}$ behind each cage. The noise was a $3.7 \mathrm{~s}, 75 \mathrm{~dB}, 2 \mathrm{kHz}$ white noise delivered through a $90 \mathrm{~W}$ three-way speaker mounted to the rear interior face of the sound-attenuating chamber holding the startle test cage. The fan was a $3.7 \mathrm{~s}$ activation of a $12 \mathrm{~V}, \mathrm{DC}, 80 \mathrm{~mm}$ brushless computer fan mounted to the top of the startle test cage which produced a salient flow of air but no measurable change in sound level. The tone was a $3.7 \mathrm{~s}, 75$ $\mathrm{dB}, 2 \mathrm{kHz}$ pure tone delivered through the same speaker as the noise. The unconditioned stimulus was a $0.5 \mathrm{~s}, 0.4 \mathrm{~mA}$ shock delivered to the floor bars of the test cage produced by a shock generator. The startle probe was a $95 \mathrm{~dB}, 50 \mathrm{~ms}, 0-22 \mathrm{kHz}$ white noise burst ( $5 \mathrm{~ms}$ rise-decay) delivered through the same speakers used to provide background noise.

\section{General experimental procedure}

For all experiments described, GDX male and female rats were implanted subcutaneously with pellets containing E, PPT, or DPN or were sham implanted and were trained as described.

\section{Slow-acquisition $A X+, B X-$ discrimination}

The training protocol was modified from that of Myers and Davis (2004), as summarized below.

Pretest. To determine any unconditioned effect of the light, noise, and fan cues, $7 \mathrm{~d}$ after hormone or sham implantation rats were placed in the startle cages and $5 \mathrm{~min}$ later presented with 30 noise bursts [ $30 \mathrm{~s}$ interstimulus interval (ISI)] intended to produce a stable startle baseline. This was followed by 40 additional startle stimuli, of which 30 occurred $2.2 \mathrm{~s}$ after the onset of the light, noise, fan, light/noise, light/fan, and fan/noise stimuli (five of each cue or cue combination). Trial types were pseudorandomly arranged. Compound stimuli were presented simultaneously.

Training. Beginning $24 \mathrm{~h}$ after the pretest, rats were returned to the startle chambers and 5 min later presented with the first of 10 noise bursts, which served to habituate the startle response to a stable baseline. Beginning $30 \mathrm{~s}$ later, rats received four training/test trials in one of two orders: $\mathrm{AX}+, \mathrm{BX}-, \mathrm{BX}-, \mathrm{AX}+$ (program $\mathrm{A})$, or $\mathrm{BX}-, \mathrm{AX}+, \mathrm{AX}+$, $\mathrm{BX}-$ (program $\mathrm{B})$. The training trials were structured as follows: $2.2 \mathrm{~s}$ after the onset of the $3.7 \mathrm{~s}$ compound cue, a $50 \mathrm{~ms}$ startle probe occurred and startle was assessed; $3.2 \mathrm{~s}$ after the onset of the compound cue, a 500 ms shock occurred (on AX+trials) or did not occur (on BX-trials). Thus, on $\mathrm{AX}+$ trials, animals received both a startle stimulus and a shock. The shock coterminated with the compound cue. Trials were separated by three presentations of the startle probe in the absence of any cue for the purpose of sampling baseline startle throughout the session. The intertrial interval (ITI) was $30 \mathrm{~s}$. Training sessions occurred daily, with programs $A$ and B used in alternating sessions for $6 \mathrm{~d}$. On every third day, training was interrupted, and a posttest session was run instead. The session began with 30 startle probe presentations, which were followed $30 \mathrm{~s}$ later by 30 additional startle stimuli, of which 15 occurred $2.2 \mathrm{~s}$ after the onset of A, B, or AB (i.e., five tests of each cue). The remaining 10 occurred in the absence of any cue for the purpose of sampling startle baseline throughout the test session. The trial types were presented pseudorandomly, and the ITI was $30 \mathrm{~s}$.

\section{Test for external inhibition}

To evaluate whether the reduction in response to the novel compound $\mathrm{AB}$ was the result of inhibitory learning and not external inhibition, rats were pretested to cues AX, BX, A, AB, and AC. The pretest began with 30 startle probes at a $30 \mathrm{~s}$ ISI to habituate startle baseline, followed by 35 additional startle probes, 25 of which occurred $3.2 \mathrm{~s}$ after the onset of AX, $\mathrm{BX}, \mathrm{A}, \mathrm{AB}$, or AC. Trials types were pseudorandomly arranged. On the following day, rats underwent pretraining exposure to cue $\mathrm{C}$ alone (15 nonreinforced presentations) to equate exposure to cue $\mathrm{C}$ with exposure to cue $\mathrm{B}$. Over the next $3 \mathrm{~d}$, rats were trained with five $\mathrm{AX}+$ and five $\mathrm{BX}-$ pairings each day ( 2 min ITI; trial types pseudorandomly arranged). For all rats, $\mathrm{A}$ was the light, $\mathrm{B}$ was the fan, $\mathrm{X}$ was the noise, and $\mathrm{C}$ was the tone. After training, rats were tested to cues $\mathrm{AX}, \mathrm{BX}, \mathrm{A}, \mathrm{AB}$, and $\mathrm{AC}$ using the same protocol as the pretest.

\section{Slow-acquisition single-cue fear-potentiated startle}

Pretest. Rats were placed into the startle cages and exposed to 30 startle probes at a $30 \mathrm{~s}$ ITI, followed by 30 additional startle probes, one-half of which occurred $3.2 \mathrm{~s}$ after the onset of the $3.7 \mathrm{~s}$ light. Trial types were pseudorandomly arranged and the ITI was $30 \mathrm{~s}$.

Training. Beginning $8 \mathrm{~d}$ after hormone replacement, rats were exposed to daily training sessions, each involving two pairings of the light with footshock and 10 startle probes, five of which were presented in darkness and five occurring $3.2 \mathrm{~s}$ after the onset of the light. In one-half of the sessions, the two light-shock pairings occurred at the beginning of the session, and in the other half, they occurred at the end. Fear-potentiated startle was defined as the percentage change in startle amplitude in the presence versus the absence of the light.

\section{Statistical analysis}

For slow-acquisition $\mathrm{AX}+, \mathrm{BX}-$ discrimination learning, data for the acquisition as well as for the posttests were analyzed with ANOVA with repeated measures with trial type (cue) and time (test day) as withinsubjects factors, followed by appropriate post hoc tests where applicable. For slow-acquisition fear-potentiated startle, data were analyzed using ANOVA with repeated measures.

\section{Methods for specific experiments}

Experiment 1: the effect of estrogen and $E R \alpha$ and $E R \beta$ activation on discrimination fear learning. To establish the effect of $\mathrm{E}$ on both the excita- 


\section{A: Females}
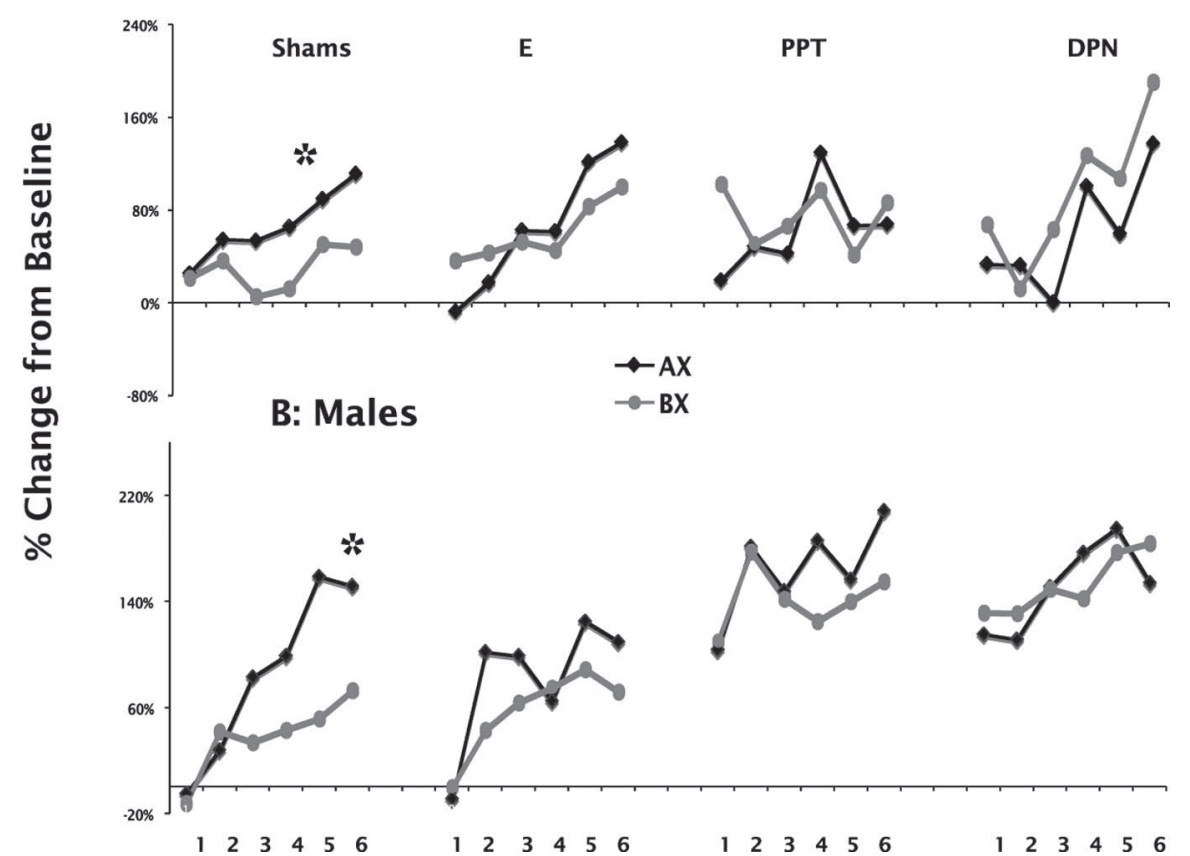

Figure 1. Acquisition of $A X$ and $B X$ discrimination over the 6 training days in sham-, E-, PPT-, and DPN-implanted GDX female rats $(\boldsymbol{A})$ and sham-, E-, PPT-, and DPN-implanted GDX male rats $(\boldsymbol{B})$. The asterisk indicates significant difference in the response to AX compared with BX.

tory and inhibitory elements of emotional learning, separate groups of GDX male and female rats were trained with a slow-acquisition version of the $\mathrm{AX}+, \mathrm{BX}-$ discrimination learning paradigm. For both experiments, rats were implanted with $21 \mathrm{~d}$ release E pellets (females, $n=23$; males, $n=16$ ) or were sham implanted (females, $n=22$; males, $n=19$ ). In addition, because the action of $\mathrm{E}$ is thought to occur primarily via activation of two cytosolic receptors, $\operatorname{ER} \alpha$ and $\operatorname{ER} \beta$, the separate contribution of each of these receptors to the excitatory and inhibitory aspects of fear learning was assessed within each sex by using extra groups of GDX male and female rats implanted with $21 \mathrm{~d}$ release pellets of PPT (an ER $\alpha$ agonist; $n=12$ female; $n=11$ male) and DPN (an ER $\beta$ agonist; $n=$ 11 female; $n=12$ male). All groups were trained for $\mathrm{AX}+, \mathrm{BX}-$ discrimination learning as described above.

Experiment 2: demonstration of inhibitory learning as opposed to external inhibition. It has been known since the time of Pavlov that a conditioned response can be disrupted when the cue is presented with another, novel cue, a phenomenon called external inhibition. To be certain that any reduction in response to the new compound, $A B$, results from conditioned rather than external inhibition, it is necessary to test fear to $\mathrm{A}$ in compound with yet another stimulus, $\mathrm{C}$, that has not been trained as a conditioned inhibitor. To evaluate this, 12 GDX females were trained to $\mathrm{AX}$ and $\mathrm{BX}$ as described above and then tested with $\mathrm{AX}, \mathrm{BX}, \mathrm{A}, \mathrm{AB}$, and AC.

Experiment 3: the effect of estrogen and specific ER $\alpha$ and ER $\beta$ activation on single-cue fear-potentiated startle. Because the role of $\mathrm{E}$ or $\mathrm{E}$ receptor modulators in emotional learning has not been established, and because in our previous studies using classical fear-conditioning procedures (two training sessions involving 20 cue-shock pairings) we did not observe learning differences between ovariectomized (OVX) control and OVX E-replaced rats, we used a modified slow-acquisition protocol in ovariectomized rats that allows measurement of the rate of fear acquisition over multiple training sessions as described previously (Kim and Davis, 1993). Using this method, we tested the effect of $\mathrm{E}$ on slow-acquisition fear conditioning in separate experiments on GDX female and male rats. In addition, we used the same methodology to test the effect of $\mathrm{ER} \alpha$ and $\mathrm{ER} \beta$ activation in separate experiments on GDX female and male rats. For the first experiment, rats were implanted subcutaneously with pellets containing $\mathrm{E}$ (females, $n=10$; males, $n=10$ ) or sham implanted (females, $n=10$; males, $n=$ $10)$. For the second experiment, rats were implanted with pellets containing PPT or DPN or were sham implanted (for both female and male groups, sham, $n=8$; PPT, $n=10$; DPN, $n=10)$.

\section{Results}

\section{Experiment 1}

Estrogen delays and $E R \alpha$ or ER $\beta$ activation disrupts the acquisition of $A X$ and $B X$ during training in both male and female rats

Figure $1 A$ shows the acquisition of $\mathrm{AX}+$ and $\mathrm{BX}-$ during training in GDX sham and E-, PPT-, or DPN-implanted female rats. The data from individual treatment groups were analyzed with ANOVA with repeated measures with training day and cue type (AX and BX) as within-subjects factors. The analysis showed that shamimplanted females did not show a significant effect of training day $\left(F_{(1,21)}=2.57\right.$; $p=0.124)$ but did show a difference in response to cue type $\left(F_{(1,21)}=8.02 ; p=\right.$ 0.01 ), indicating that this group discriminated between AX and BX very early in training. E-implanted females showed a significant effect of training day $\left(F_{(1,22)}=\right.$ $6.8 ; p=0.016)$ but no significant difference in the response to cue type $(F<1)$. PPT- and DPN-implanted females showed no significant difference in either training day or cue type (PPT training day, $F_{(1,11)}=$ $0.629, p=0.445$; cue type, $F<1$; DPN training day, $F_{(1,10)}=$ $2.000, p=0.188$; cue type, $\left.F_{(1,10)}=2.148, p=0.173\right)$. Examination of the data in Figure $1 \mathrm{~A}$ shows that whereas the E-implanted group is progressing in the same direction as the sham controls, the PPT-implanted females were not discriminating between AX and $\mathrm{BX}$, and the DPN-implanted females were responding more to BX than AX throughout most of the training days.

Figure $1 B$ shows the acquisition of $\mathrm{AX}+$ and $\mathrm{BX}-$ during training in sham-, E-, PPT-, or DPN-implanted male rats. The data from individual treatment groups were analyzed with repeated-measures ANOVA, with training day and cue type as within-subjects factors. Sham-implanted males showed a significant effect of training day $\left(F_{(1,18)}=7.46 ; p=0.014\right)$, and cue type $\left(F_{(1,18)}=15.49 ; p=0.001\right)$, indicating that, like the shamimplanted females, this group discriminated between AX and BX early in training, and in contrast to sham-implanted females, sham-implanted males showed an increase in overall response over training days. E-implanted males showed no significant effect of training day $\left(F_{(1,15)}=2.358 ; p=0.145\right)$ or cue type $\left(F_{(1,15)}\right.$ $=1.266 ; p=0.287)$. PPT- and DPN-implanted males showed no significant difference in either training day or cue type (PPT training day, $F_{(1,10)}=1.95, p=0.192$; cue type, $F_{(1,10)}=2.03, p=$ 0.19 ; DPN training day, $F_{(1,11)}=2.54, p=0.139$; cue type, $F<1$ ). As with the females, it can been seen in Figure $1 B$ that E-implanted males were progressing in the same manner as sham-implanted males, whereas PPT-implanted males sometimes showed no difference in response to AX versus BX and sometimes showed an elevated response to AX over BX. DPNimplanted males show no clear progression in the response to $\mathrm{AX}$ and BX. 


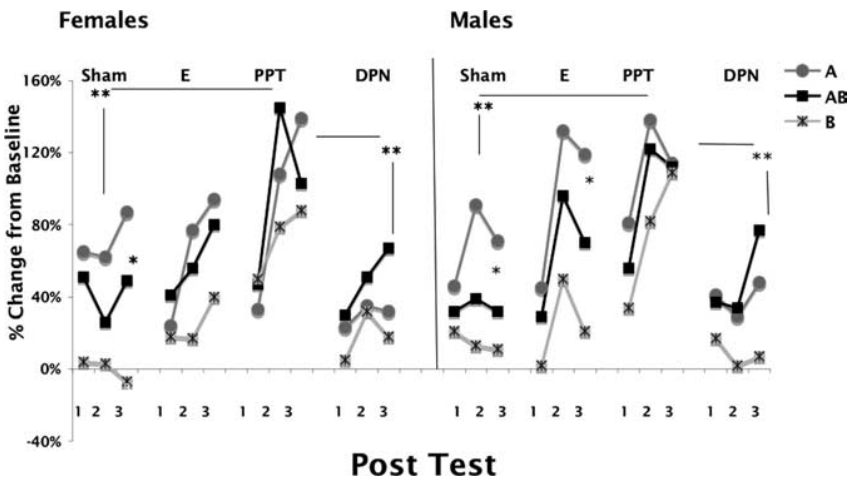

Figure 2. Percentage change from baseline of fear-potentiated startle to cues $A, B$, and $A B$ in three posttests during slow-acquisition $\mathrm{AX}+, \mathrm{BX}$ - discrimination training in sham-, E-, PPTand DPN-implanted GDX female rats (left) and sham-, E-, PPT- and DPN-implanted GDX male rats (right). ${ }^{*}$ Significant reduction in the response to $A B$ compared with $A ;{ }^{*}$ significant difference in the overall expression of discrimination learning between groups.

Overall expression of $A X+, B X-$ discrimination learning

Figure 2 (left) shows the results of $\mathrm{AX}+, \mathrm{BX}-$ discrimination learning over the course of the three posttests in GDX females implanted with blank pellets (sham), E, the ER $\alpha$ agonist PPT, or the ER $\beta$ agonist DPN. ANOVA with repeated measures using group, day, and trial type $(\mathrm{A}, \mathrm{AB}$, and $\mathrm{B})$ as factors showed significant main effects of group $\left(F_{(3,64)}=3.34 ; p=0.025\right)$, day $\left(F_{(1,64)}=3.87 ; p=0.05\right)$, and trial type $\left(F_{(1,64)}=12.38 ; p=\right.$ $0.001)$. Post hoc analysis found a significant difference between the DPN-implanted group and the PPT-implanted group ( $p=$ 0.04 ) and the PPT-implanted group and the sham-implanted group ( $p=0.03$ ), suggesting opposite effects of $\operatorname{ER} \alpha$ and $\operatorname{ER} \beta$ stimulation in discrimination learning with $\mathrm{ER} \alpha$ activation resulting in a significantly enhanced response compared with ER $\beta$ activation or a lack of E receptor activation altogether. Figure 2 (right) shows the same test results from GDX males. ANOVA with repeated measures showed a main effect of group $\left(F_{(3,54)}=\right.$ $2.73 ; p=0.05)$, day $\left(F_{(1,54)}=4.05 ; p=0.049\right)$, and trial type $\left(F_{(1,54)}=21.450 ; p<0.001\right)$. As with the females, post hoc analysis showed that PPT-implanted rats differed significantly from DPN-implanted $(p=0.015)$ and from sham-implanted $(p=$ 0.018 ) rats, again indicating opposite effects of $\operatorname{ER} \alpha$ and $\operatorname{ER} \beta$ stimulation in discrimination learning. Overall comparison of both sexes and all treatment groups found significant group differences $\left(F_{(7,118)}=2.63 ; p=0.015\right)$. Post hoc analysis showed that in addition to the within-sex differences stated above, male PPTimplanted rats had significantly higher FPS responses than female DPN-implanted rats $(p=0.008)$, and female PPTimplanted rats had significantly higher startle responses than male DPN-implanted rats $(p=0.015)$. Sham-implanted females differed from PPT-implanted males ( $p=0.005)$, and shamimplanted males differed from PPT-implanted females $(p=$ 0.015). Hence, the effect of heightened response to ER $\alpha$ exists between, as well as within, the sexes.

There were no significant differences between the overall response of sham-implanted male and female rats or between those of E-implanted male and female rats. There was no significant difference between sham- and E-implanted male rats or between sham- and E-implanted female rats.

The SEMs for each posttest and treatment group are shown in Table 1.
Table 1. SEM (in \%) for the posttests

\begin{tabular}{|c|c|c|c|c|c|c|c|c|c|}
\hline & \multicolumn{3}{|c|}{ Posttest 1} & \multicolumn{3}{|c|}{ Posttest 2} & \multicolumn{3}{|c|}{ Posttest 3} \\
\hline & $A$ & $A B$ & $B$ & A & $A B$ & $B$ & A & $A B$ & B \\
\hline \multicolumn{10}{|l|}{ Female } \\
\hline Sham & 20 & 21 & 10 & 15 & 12 & 10 & 19 & 19 & 8 \\
\hline$E$ & 13 & 25 & 7 & 25 & 19 & 13 & 23 & 22 & 22 \\
\hline PPT & 17 & 21 & 12 & 37 & 42 & 26 & 53 & 40 & 33 \\
\hline DPN & 14 & 28 & 13 & 18 & 36 & 21 & 18 & 40 & 13 \\
\hline \multicolumn{10}{|l|}{ Male } \\
\hline Sham & 13 & 17 & 13 & 30 & 15 & 16 & 14 & 16 & 13 \\
\hline $\mathrm{E}$ & 19 & 13 & 8 & 32 & 24 & 12 & 48 & 30 & 12 \\
\hline PPT & 23 & 31 & 27 & 52 & 44 & 31 & 42 & 52 & 53 \\
\hline DPN & 16 & 16 & 10 & 10 & 15 & 10 & 23 & 29 & 9 \\
\hline
\end{tabular}

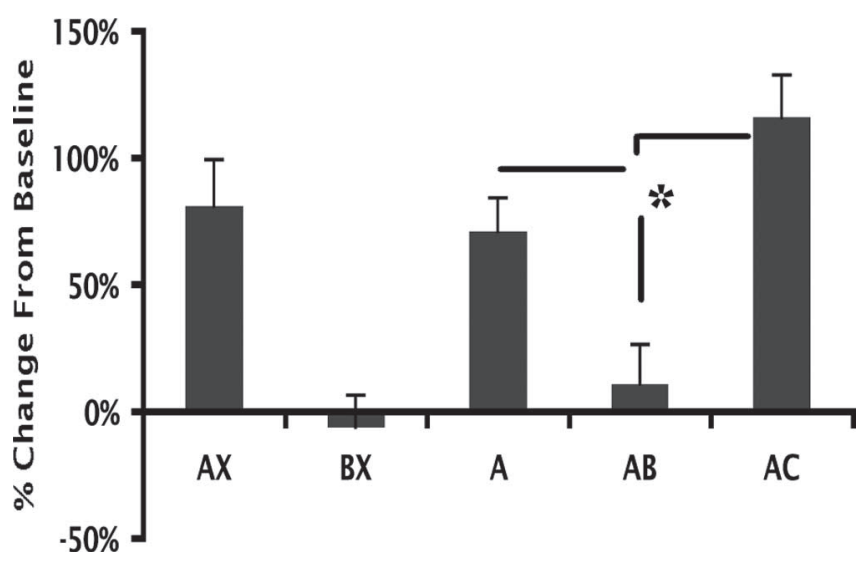

Figure 3. Percentage change from baseline of fear-potentiated startle to $A X, B X, A, A B$, and a new compound, $A C$, presented for the first time, after $A B+, B X$ - discrimination training in $G D X$ female rats. *The response to $A B$ is significantly less than to $A$ and $A C$.

$A$ versus $A B$ : estrogen disrupts the inhibition of fear in female rats only

The most important comparison within the posttests is the response of A compared with AB. This is because a significantly lower response to $\mathrm{AB}$ than to $\mathrm{A}$ indicates generalization of a safety signal to a new situation and therefore demonstrates a successful inhibition of fear. It is important to reiterate that cue B presented alone is not inhibiting fear, but simply not eliciting or activating any fear response. Cue B actively inhibits fear when presented along with a fear-inducing stimulus (that is, when it is presented in conjunction with cue A). Using repeated-measures ANOVA with day and cue type as within-subjects factors, analysis of the data from posttest 2 and posttest 3 for all individual treatment groups within each sex (Fig. 2) showed that sham-implanted females and males showed successful inhibition to $\mathrm{AB}$ (females, $F_{(1,21)}=10.61, p=0.004$; males, $\left.F_{(1,18)}=9.33, p=0.007\right)$. E-implanted female rats failed to show this generalization of inhibition $(F<1)$, whereas E-implanted male rats generalized successfully $\left(F_{(1,15)}=6.456 ; p=0.023\right)$. In both male and female rats, neither the $\operatorname{ER} \alpha$ agonist- nor the $\operatorname{ER} \beta$ agonist-implanted groups responded significantly lower to $\mathrm{AB}$ than to A over the last two posttests, indicating that activating only one of these receptors interfered with the expression of inhibitory learning in both sexes.

Experiment 2: the reduced response to $\mathrm{AB}$ compared with $\mathrm{A}$ represents conditioned inhibition

Results (ANOVA with repeated measures) (Fig. 3) show that females exhibited significant discrimination learning $\left(F_{(4,44)}=\right.$ 


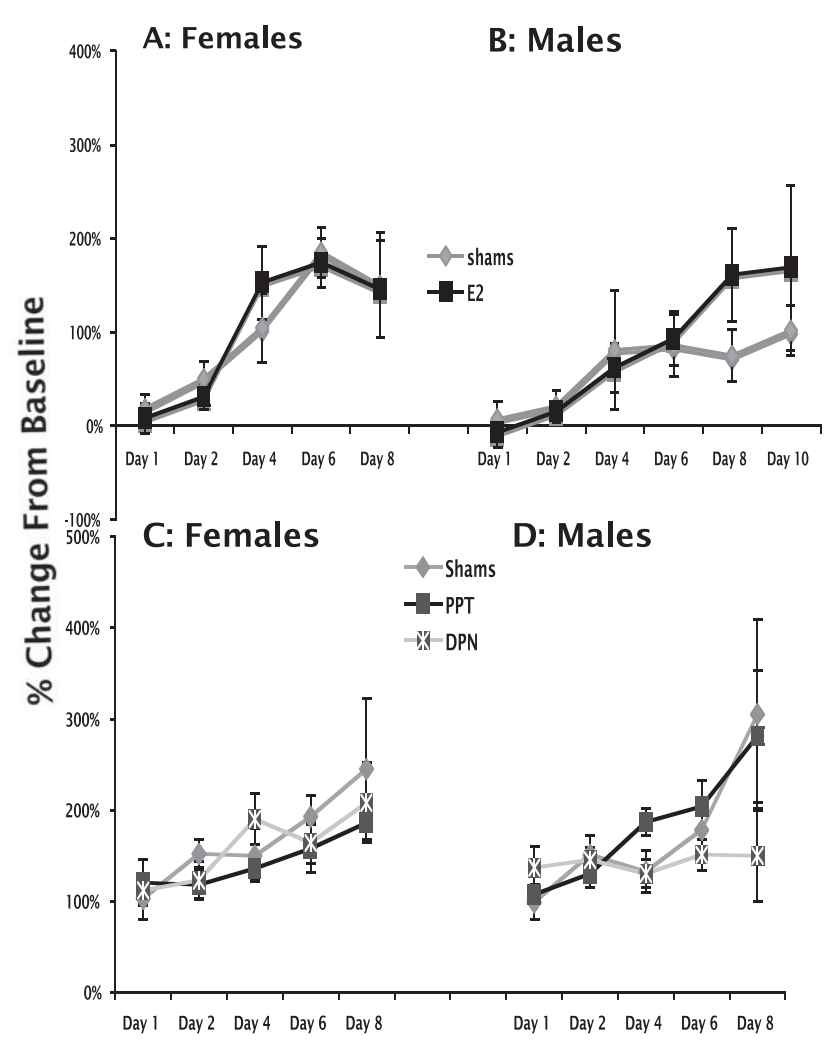

Figure 4. Acquisition of single-cue fear-potentiated startle in GDX sham- or E-implanted female rats $(\boldsymbol{A})$, sham- or E-implanted male rats $(\boldsymbol{B})$, sham or PPT- and DPN-implanted female rats $(\boldsymbol{C})$, and sham or PPT- and DPN-implanted male rats $(\boldsymbol{D})$.

$17.87 ; p<0.001)$ and displayed a lower response to the compound $\mathrm{AB}$ than to A (paired $t$ test, $p=0.009$ ), indicating successful generalization of the safety cue B. Importantly, startle in the presence of the novel compound AC (i.e., not seen during training) was significantly higher than to the novel compound $\mathrm{AB}$ (paired $t$ test, $p=0.001$ ). Hence, it is very unlikely that the reduced response observed to the novel compound $\mathrm{AB}$, in our original data (presented above), was the result of external inhibition. Therefore, we are confident that the decreased response from $\mathrm{A}$ to $\mathrm{AB}$ in the studies presented here represents conditioned inhibition, which is disrupted by selective activation of either $\mathrm{ER} \alpha$ or $\mathrm{ER} \beta$ in both males and females and by $\mathrm{E}$ in females.

\section{Experiment 3: estrogen and specific $\operatorname{ER} \alpha$ and $\operatorname{ER} \beta$ activation do not effect single-cue fear-potentiated startle in male or female rats}

Figure $4, A$ (females) and $B$ (males), shows the acquisition and expression of fear-potentiated startle over 8 training days with and without E replacement. ANOVA with repeated measures showed a significant effect of training in both sexes (females, $F_{(1,18)}=9.69, p=0.006$; males, $\left.F_{(1,18)}=5.14, p=0.036\right)$, and no effect of E replacement in either female $(F<1)$ or male $(F<1)$ rats. There was no significant interaction between treatment and training day in either female or male rats $(F<1)$ for both females and males). Because there seemed to be an effect of $E$ on males on day 8 , an extra day of training was given to the male group, after which the difference disappeared (day 10 mean \pm SEM, shams, $102 \pm 27$; E-replaced, $162 \pm 87)$. There was no difference in fear-potentiated startle when E-implanted and sham-implanted males and females were compared by sex and treatment groups $\left(F_{(3,36)}=2.130 ; p=0.114\right)$. These data indicate that there was no change in either the acquisition or expression of conditioned fear associated with sex or the presence of $\mathrm{E}$ in paradigms examining only the excitatory elements of fear learning.

Results presented in Figure 4, $C$ (females) and $D$ (males), showed that although there was a significant effect of training in both the female and male groups (female, $F_{(1,25)}=5.53, p=$ 0.027 ; male, $\left.F_{(1,25)}=6.40, p=0.018\right)$, there was no significant effect of either the ER $\alpha$ agonist PPT or the ER $\beta$ agonist DPN on the acquisition and expression of fear-potentiated startle in female $(F<1)$ or male $\left(F_{(2,25)}=1.167 ; p=0.328\right)$ rats and no significant interaction between treatment and training day in female $(F<1)$ or male $\left(F_{(2,25)}=1.560 ; p=0.23\right)$ rats. In male rats, the ER $\beta$ agonist DPN appeared to limit the extent of fear conditioning that occurred; however, this was not a significant difference over the $8 \mathrm{~d}$ training period used here. Thus, specific activation of either ER $\alpha$ or ER $\beta$ did not significantly affect excitatory fear learning. Moreover, there was no significant difference in the acquisition and expression of fear-potentiated startle when males and females were compared by sex and treatment $(F<1)$.

\section{Discussion}

Results show that sham- and E-replaced rats of both sexes learn to distinguish between the excitatory cue $\mathrm{A}$ and the nonexcitatory cue $\mathrm{B}$ in $\mathrm{AX}+, \mathrm{BX}$ - discrimination learning. However, whereas sham-implanted male and female rats and E-implanted males were able to generalize inhibitory learning about the safety cue $\mathrm{B}$ to a new situation (i.e., lower FPS to AB than to A), E-implanted females did not demonstrate the ability to actively suppress fear. In contrast, $\mathrm{E}$ does not enhance the response of male or female rats to the excitatory cue in either $\mathrm{AX}+, \mathrm{BX}-$ discrimination learning or in single-cue fear conditioning. Thus, data presented here suggest that $\mathrm{E}$ is not increasing fear per se but specifically interfering with the ability to inhibit it.

This is the first demonstration that $\mathrm{E}$ interferes with fear inhibition independent of an effect on the level of fear itself. E has been reported to delay extinction (another form of inhibitory learning) in a one-way avoidance task in females (Telegdy and Stark, 1973) and to maintain the level of passive avoidance that is typically reduced in rats treated with a benzodiazepine (Gibbs et al., 1998). However, because rate of extinction is often a more sensitive measure of the level of fear than the terminal level of fear at the end of acquisition (Annau and Kamin, 1961), it cannot be clear whether this was a direct effect on fear inhibition or a reflection of a higher level of fear in these tasks. Thus, although one cannot be sure from the design of these studies whether E interfered with inhibitory learning, they are certainly consistent with this idea.

Reports in humans point in the same direction. Women in the late follicular stage of the menstrual cycle, when E levels are high and progesterone levels are low, show less recall of extinction than men or than women in the early follicular stage (Milad et al., 2006b), suggesting that $\mathrm{E}$ is expressly hindering inhibitory learning in human females. Functional magnetic resonance imaging (fMRI) of women in the late follicular, compared with those in the early follicular, stage show decreased activation of brain regions involved in behavioral inhibition, including the orbitofrontal cortex and anterior cingulate gyrus, in response to aversive pictures (Goldstein et al., 2005), indicating that high E reduces the responsiveness of these regions to emotional stimuli. Moreover, an fMRI study by Protopopescu et al. (2005) showed that activation of the medial orbital frontal cortex was lower in midcycle (again the late follicular stage) relative to the premenstrual phase and that this differential activation was exaggerated when 
women were performing an inhibitory task, demonstrating that high levels of estrogen specifically reduce activity in this area. These investigations evince that $\mathrm{E}$ interferes specifically with emotional inhibition in women.

Studies also suggest that E combined with stress or emotional arousal causes deficits in other types of behavioral inhibition. For example, activation of central stress systems by a benzodiazepine inverse agonist impairs proestrous or E-replaced GDX females rats at lower doses than males or estrous females in a working memory task (Shansky et al., 2004), and stress disrupts the performance of E-replaced GDX female rats in a water-escape delayed-matching-to-sample problem (O'Neal et al., 1996). In female rhesus macaques trained to identify the new face in an ever-increasing array of human, chimpanzee, and rhesus monkey faces, females on $\mathrm{E}$ showed a deficit only when the task was done using faces of conspecifics. It was hypothesized that estrogen produced this deficit by enhancing reactivity to emotionally significant stimuli (Lacreuse and Herndon, 2003). As with AX+, BXdiscrimination learning, these studies support the idea that $\mathrm{E}$, along with emotional arousal and/or aversive stimuli, interferes with tasks that require a form of behavioral inhibition to make the correct response.

The inhibition of fear to A by B did not occur in either male or female rats implanted with either the $\mathrm{ER} \alpha$ (PPT) or the ER $\beta$ (DPN) agonist, indicating that activation of either receptor alone interferes with the transfer of inhibition. In both sexes, startle amplitude to all cues by the second posttest was higher in the PPT- compared with the DPN-implanted rats, signifying that activation of the two receptor subtypes may have opposing effects in discrimination learning. Contrary to this, there was no significant learning decrement in fear-conditioning to an excitatory cue alone in either PPT- or DPN-implanted male or female rats, implying that activation of $\mathrm{ER} \alpha$ or $\mathrm{ER} \beta$ only becomes important in emotional learning paradigms that contain an inhibitory element.

$\mathrm{ER} \alpha$ stimulation increases behavioral activation or is anxiogenic, and $\operatorname{ER} \beta$ is anxiolytic, in virtually all tests of anxiety in the rat (Morgan and Pfaff, 2001; Walf et al., 2004; Lund et al., 2005; Walf and Frye, 2005). Moreover, $\mathrm{ER} \alpha$ activates and ER $\beta$ inhibits many of the same gene targets. For example, ER $\alpha$ activates and $\mathrm{ER} \beta$ inhibits gene transcription at the AP1 response element (Paech et al., 1997), and $\mathrm{ER} \alpha$ enhances activity whereas $\mathrm{ER} \beta$ reduces activity in the promoter region of the urocortin receptor gene (Haeger et al., 2006). It has been found that $\operatorname{ER} \beta$ forms heterodimers with $\mathrm{ER} \alpha$ and acts to repress the activational effects of ER $\alpha$ on gene expression (Hall and McDonnell, 1999). Indeed, results from several studies suggest that the main function of ER $\beta$ is to attenuate the function of $\mathrm{ER} \alpha$ (McInerney et al., 1998; Cowley and Parker, 1999; Weihua et al., 2000). Although PPT disrupted discrimination learning in male and female rats, the enhanced overall responsiveness of both sexes implanted with PPT suggest that, although $\mathrm{E}$ itself does not increase fear responding after $\mathrm{AX}+, \mathrm{BX}-$ training, activation of ER $\alpha$ alone does. Perhaps in learning situations that contain both excitatory and inhibitory components, unbridled $\mathrm{ER} \alpha$ stimulation initiates activational events that are usually counteracted by $\operatorname{ER} \beta$.

The interaction between $\operatorname{ER} \alpha$ and $\operatorname{ER} \beta$ may be particularly important in brain regions involved in $\mathrm{AX}+, \mathrm{BX}-$ discrimination fear learning. The amygdala and its cytologically similar extension, the bed nucleus of the stria terminalis (BNST), contain both types of estrogen receptors (Laflamme et al., 1998). Moreover, areas in the frontal cortex that project to the amygdala and the BNST and are implicated in the inhibition of fear-related behavior (Milad et al., 2006a) also contain both ER subtypes (Kritzer, 2002). Therefore, the elevation of $\mathrm{E}$ in an emotional learning task in which inhibitory behavior is important would cause activation of both $\operatorname{ER} \alpha$ and $\operatorname{ER} \beta$ within this network. Thus, sex-specific $\operatorname{ER} \alpha$ and $\operatorname{ER} \beta$ distributions, or the relative ratio of $\mathrm{ER} \alpha$ to $\mathrm{ER} \beta$ in limbic structures, may have a profound effect on emotional behavior. Although there have been many studies looking at the regional distribution of $\mathrm{ER} \alpha$ and $\mathrm{ER} \beta$, most of these looked at mRNA rather than receptor protein levels, and to our knowledge, only one study looked at sex differences in ER $\beta$ level in limbic regions. This study (Zhang et al., 2002) showed that female rats have greater $\mathrm{ER} \beta$ in the lateral and medial nuclei of the amygdala and less in the BNST than males. The BNST has been shown to be critically involved in anxiety behaviors (Davis and Shi, 1999), and many studies indicate that sex differences in anxiety are mediated at the level of this limbic structure (Francis et al., 2002; Bangasser et al., 2005; Toufexis et al., 2005; Shors, 2006). Thus, males may be less sensitive than females to the disruptive effects of $\mathrm{E}$ on the inhibition of fear because they have more $\operatorname{ER} \beta$ in the BNST or other structures that mediate anxiety and/or are involved in the inhibition of fear. It is interesting to note that in simple fear-conditioning to an excitatory cue alone, the ER $\beta$-agonist DPN produced a plateau effect in male rats that was not observed in females, suggesting that the fear response may be limited by ER $\beta$ activation in male but not in female rats.

These data may be particularly relevant regarding the inability to inhibit fear observed in posttraumatic stress disorder (PTSD) (Nemeroff et al., 2006). A recent study using the AX+, BXparadigm found that men with active PTSD symptoms showed normal discrimination between AX and BX but failed to inhibit fear to $A$ on $A B$ test trials ( $T$. Jovanovic, unpublished results), providing evidence that the ability to generalize a safety signal is disrupted in PTSD. Because the incidence of PTSD in women is at least twice that of men (Gavranidou and Rosner, 2003), the disruptive effect of $\mathrm{E}$ in female rats observed here may be important to the etiology of this pathology in women.

In summary, results show that the inhibition of fear was disrupted in the presence of $\mathrm{E}$ in female rats, suggesting that elevated E may render females more vulnerable to the negative effects of stress or emotional trauma than males. Data also showed that either $\mathrm{ER} \alpha$ or $\mathrm{ER} \beta$ activation alone disrupted discrimination learning and produced opposite effects on overall FPS levels. The detrimental effects of $\mathrm{E}$ and of individual $\mathrm{ER} \alpha$ and $\mathrm{ER} \beta$ activation did not occur in either sex when fear conditioning was done to an excitatory cue alone. Thus, $\mathrm{E}$ in female rats may cause a specific deficit in the ability to inhibit fear responding.

\section{References}

Anagnostaras SG, Maren S, DeCola JP, Lane NI, Gale GD, Schlinger BA, Fanselow MS (1998) Testicular hormones do not regulate sexually dimorphic pavlovian fear conditioning or perforant-path long-term potentiation in adult male rats. Behav Brain Res 92:1-9.

Annau Z, Kamin LJ (1961) The conditioned emotional response as a function of intensity of the US. J Comp Physiol Psychol 54:428-432.

Bangasser DA, Santollo J, Shors TJ (2005) The bed nucleus of the stria terminalis is critically involved in enhancing associative learning after stressful experience. Behav Neurosci 119:1459-1466.

Casada JH, Roache JD (2005) Behavioral inhibition and activation in posttraumatic stress disorder. J Nerv Ment Dis 193:102-109.

Cassella JV, Davis M (1986) The design and calibration of a startle measurement system. Physiol Behav 36:377-383.

Cloitre M, Yonkers KA, Pearlstein T, Altemus M, Davidson KW, Pigott TA, Shear MK, Pine D, Ross J, Howell H, Brogan K, Rieckmann N, Clemow L (2004) Women and anxiety disorders: implications for diagnosis and treatment. CNS Spectr 9:1-16. 
Cowley SM, Parker MG (1999) A comparison of transcriptional activation by ER alpha and ER beta. J Steroid Biochem Mol Biol 69:165-175.

Davis M, Shi C (1999) The extended amygdala: are the central nucleus of the amygdala and the bed nucleus of the stria terminalis differentially involved in fear versus anxiety? Ann NY Acad Sci 877:281-291.

Davis M, Myers KM, Chhatwal J, Ressler KJ (2006) Pharmacological treatments that facilitate extinction of fear: relevance to psychotherapy. NeuroRx 3:82-96.

Diaz-Veliz G, Soto V, Dussaubat N, Mora S (1989) Influence of the estrous cycle, ovariectomy and estradiol replacement upon the acquisition of conditioned avoidance responses in rats. Physiol Behav 46:397-401.

Francis DD, Young LJ, Meaney MJ, Insel TR (2002) Naturally occurring differences in maternal care are associated with the expression of oxytocin and vasopressin (V1a) receptors: gender differences. J Neuroendocrinol 14:349-353.

Gavranidou M, Rosner R (2003) The weaker sex? Gender and posttraumatic stress disorder. Depress Anxiety 17:130-139.

Gibbs RB, Burke AM, Johnson DA (1998) Estrogen replacement attenuates effects of scopolamine and lorazepam on memory acquisition and retention. Horm Behav 34:112-125.

Goldstein JM, Jerram M, Poldrack R, Ahern T, Kennedy DN, Seidman LJ, Makris N (2005) Hormonal cycle modulates arousal circuitry in women using functional magnetic resonance imaging. J Neurosci 25:9309-9316.

Gupta RR, Sen S, Diepenhorst LL, Rudick CN, Maren S (2001) Estrogen modulates sexually dimorphic contextual fear conditioning and hippocampal long-term potentiation (LTP) in rats. Brain Res 888:356-365.

Haeger P, Andres ME, Forray MI, Daza C, Araneda S, Gysling K (2006) Estrogen receptors $\alpha$ and $\beta$ differentially regulate the transcriptional activity of the Urocortin gene. J Neurosci 26:4908-4916.

Hall JM, McDonnell DP (1999) The estrogen receptor beta-isoform (ERbeta) of the human estrogen receptor modulates ERalpha transcriptional activity and is a key regulator of the cellular response to estrogens and antiestrogens. Endocrinology 140:5566-5578.

Kim M, Davis M (1993) Electrolytic lesions of the amygdala block acquisition and expression of fear-potentiated startle even with extensive training but do not prevent reacquisition. Behav Neurosci 107:580-595.

Kritzer MF (2002) Regional, laminar, and cellular distribution of immunoreactivity for ER alpha and ER beta in the cerebral cortex of hormonally intact, adult male and female rats. Cereb Cortex 12:116-128.

Lacreuse A, Herndon JG (2003) Estradiol selectively affects processing of conspecifics' faces in female rhesus monkeys. Psychoneuroendocrinology 28:885-905.

Laflamme N, Nappi RE, Drolet G, Labrie C, Rivest S (1998) Expression and neuropeptidergic characterization of estrogen receptors (ERalpha and ERbeta) throughout the rat brain: anatomical evidence of distinct roles of each subtype. J Neurobiol 36:357-378.

Lund TD, Rovis T, Chung WC, Handa RJ (2005) Novel actions of estrogen receptor-beta on anxiety-related behaviors. Endocrinology 146:797-807.

Markus JS (1997) Sex differences and estrous cycle changes in hippocampaldependent fear conditioning. Psychobiology 25:246-252.

McInerney EM, Weis KE, Sun J, Mosselman S, Katzenellenbogen BS (1998) Transcription activation by the human estrogen receptor subtype beta (ER beta) studied with ER beta and ER alpha receptor chimeras. Endocrinology 139:4513-4522.

McNally RJ (1997) Memory and anxiety disorders. Philos Trans R Soc Lond B Biol Sci 352:1755-1759.

Meyers MJ, Sun J, Carlson KE, Marriner GA, Katzenellenbogen BS, Katzenellenbogen JA (2001) Estrogen receptor-beta potency-selective ligands: structure-activity relationship studies of diarylpropionitriles and their acetylene and polar analogues. J Med Chem 44:4230-4251.

Milad MR, Rauch SL, Pitman RK, Quirk GJ (2006a) Fear extinction in rats: implications for human brain imaging and anxiety disorders. Biol Psychol 73:61-71.

Milad MR, Goldstein JM, Orr SP, Wedig MM, Klibanski A, Pitman RK, Rauch
SL (2006b) Fear conditioning and extinction: influence of sex and menstrual cycle in healthy humans. Behav Neurosci 120:1196-1203.

Morgan MA, Pfaff DW (2001) Effects of estrogen on activity and fearrelated behaviors in mice. Horm Behav 40:472-482.

Myers KM, Davis M (2004) AX+, BX- discrimination learning in the fearpotentiated startle paradigm: possible relevance to inhibitory fear learning in extinction. Learn Mem 11:464-475.

NemeroffCB, Bremner JD, Foa EB, Mayberg HS, North CS, Stein MB (2006) Posttraumatic stress disorder: a state-of-the-science review. J Psychiatr Res 40:1-21.

O’Neal MF, Means LW, Poole MC, Hamm RJ (1996) Estrogen affects performance of ovariectomized rats in a two-choice water-escape working memory task. Psychoneuroendocrinology 21:51-65.

Paech K, Webb P, Kuiper GG, Nilsson S, Gustafsson J, Kushner PJ, Scanlan TS (1997) Differential ligand activation of estrogen receptors ERalpha and ERbeta at AP1 sites. Science 277:1508-1510.

Protopopescu X, Pan H, Altemus M, Tuescher O, Polanecsky M, McEwen B, Silbersweig D, Stern E (2005) Orbitofrontal cortex activity related to emotional processing changes across the menstrual cycle. Proc Natl Acad Sci USA 102:16060-16065.

Pryce CR, Lehmann J, Feldon J (1999) Effect of sex on fear conditioning is similar for context and discrete CS in Wistar, Lewis and Fischer rat strains. Pharmacol Biochem Behav 64:753-759.

Shansky RM, Glavis-Bloom C, Lerman D, McRae P, Benson C, Miller K, Cosand L, Horvath TL, Arnsten AF (2004) Estrogen mediates sex differences in stress-induced prefrontal cortex dysfunction. Mol Psychiatry 9:531-538.

Shors TJ (2006) Stressful experience and learning across the lifespan. Annu Rev Psychol 57:55-85.

Shors TJ, Leuner B (2003) Estrogen-mediated effects on depression and memory formation in females. J Affect Disord 74:85-96.

Singh M, Meyer EM, Millard WJ, Simpkins JW (1994) Ovarian steroid deprivation results in a reversible learning impairment and compromised cholinergic function in female Sprague-Dawley rats. Brain Res 644:305-312.

Stauffer SR, Sun J, Katzenellenbogen BS, Katzenellenbogen JA (2000) Acyclic amides as estrogen receptor ligands: synthesis, binding, activity and receptor interaction. Bioorg Med Chem 8:1293-1316.

Stock HS, Caldarone B, Abrahamsen G, Mongeluzi D, Wilson MA, Rosellini RA (2001) Sex differences in relation to conditioned fear-induced enhancement of morphine analgesia. Physiol Behav 72:439-447.

Telegdy G, Stark A (1973) Effect of sexual steroids and androgen sterilization on avoidance and exploratory behaviour in the rat. Acta Physiol Acad Sci Hung 43:55-63.

Toufexis D, Davis C, Hammond A, Davis M (2005) Sex differences in hormonal modulation of anxiety measured with light-enhanced startle: possible role for arginine vasopressin in the male. J Neurosci 25:9010-9016.

Wagner AR, Logan FA, Haberlandt K, Price T (1968) Stimulus selection in animal discrimination learning. J Exp Psychol 76:171-180.

Walf AA, Frye CA (2005) ERbeta-selective estrogen receptor modulators produce antianxiety behavior when administered systemically to ovariectomized rats. Neuropsychopharmacology 30:1598-1609.

Walf AA, Rhodes ME, Frye CA (2004) Antidepressant effects of ERbetaselective estrogen receptor modulators in the forced swim test. Pharmacol Biochem Behav 78:523-529.

Weihua Z, Saji S, Makinen S, Cheng G, Jensen EV, Warner M, Gustafsson JA (2000) Estrogen receptor (ER) beta, a modulator of ERalpha in the uterus. Proc Natl Acad Sci USA 97:5936-5941.

Wood GE, Shors TJ (1998) Stress facilitates classical conditioning in males, but impairs classical conditioning in females through activational effects of ovarian hormones. Proc Natl Acad Sci USA 95:4066-4071.

Zhang JQ, Cai WQ, Zhou DS, Su BY (2002) Distribution and differences of estrogen receptor beta immunoreactivity in the brain of adult male and female rats. Brain Res 935:73-80. 